\title{
Dioxin, diet and disease on St Kilda
}

\author{
P Stride \\ Physician, Redcliffe Hospital, Redcliffe, Queensland, Australia
}

\begin{abstract}
The inhabitants of St Kilda are well known for their susceptibility to infection. Low herd immunity, limited genetic biodiversity, malnutrition and poor social conditions have been incriminated as the major predisposing factors, but the clinical evidence for the effect of malnutrition and the clinical relevance of the more recent discovery of heavy metal and dioxin pollution on infectious diseases have not been scrutinised from a medical perspective.
\end{abstract}

KEYWORDS Chloracne, dioxin, infectious diseases, malnutrition, St Kilda, vitamin C DECLARATION OF INTERESTS No conflict of interests declared.
Published online March 2009

Correspondence to $\boldsymbol{P}$ Stride, Redcliffe Hospital, Locked Bag I, Redcliffe, Queensland, Australia 4020

tel. +61732567980

e-mail

peter_stride@health.qld.gov.au

\section{INTRODUCTION}

The inhabitants of St Kilda were known to suffer from infectious diseases, perhaps more severely than other inhabitants of the Hebrides. Rev. Neil MacKenzie, minister on St Kilda from 1829-43, wrote that 'when hooping cough, measles or scarlet fever visit the island, there are more than the average number of deaths' and 'the diseases to which they are most subject are spotted fever, dyspepsia and nervous disorders, with swelling and bowing of their limbs'.' Tetanus, ${ }^{2}$ smallpox, ${ }^{3}$ measles $^{4}$ and respiratory infections ${ }^{5}$ are well documented. Harman ${ }^{6}$ noted epidemics of typhus and whooping cough in 1892, influenza in 1901, 1913 and 1914, mumps in 1920, whooping cough in 1921, pneumonia in 1924 and influenza in 1926. Leprosy, tuberculosis and many other infections played a smaller role in the morbidity and mortality of this isolated community. Predisposing factors tradionally have been thought to be low herd immunity, an inclement climate and malnutrition. Limited biodiversity of histocompatibility antigens ${ }^{3}$ in an inbred community and recently discovered environmental toxins may have also contributed to the St Kildans' susceptibility to infection.

\section{DIET, VITAMINS AND HEAVY METALS}

The church ministers and historians of St Kilda ${ }^{6-14}$ all gave details of the islanders' food sources and diet, although none gave a detailed year-round description of their daily consumption of vegetables or other food, so we cannot calculate the average daily intake of vitamins. There are no laboratory studies that assessed nutrient levels in the islanders. Rev. Alexander Buchan attributed his poor health while on St Kilda to malnutrition, and required time away to improve his health. ${ }^{13}$ Staff-Surgeon Scott, who visited St Kilda in 1887, detected rheumatism, dyspepsia, anaemia, childhood palpitations and incipient scurvy. ${ }^{14}$

The islanders' diet of flesh and eggs, with a lack of fruit and vegetables, would have been deficient in vitamin $C$ and probably in the B group vitamins. In 1912, after a severe winter and the late arrival of supplies in spring on HMS Achilles, Dougal MacLean, the island missionary, told the ship's captain that the population had survived on tea, bread and butter from early March to May. ${ }^{13}$ Many appreciated there were periods of food shortages. Salient points are as follows:

- The islanders devoted time mainly to catching seabirds and collecting their eggs, secondly to attending to cattle and sheep and lastly to tending the limited arable land. Sheep and a few cattle were slaughtered for food on special occasions. The St Kildans did not rotate crops nor leave areas fallow for a season.

- The mainstays of their food were gannet and fulmar, which were consumed either as eggs and/or as young birds, both fresh and cured. Large numbers of cured birds were kept in cleitans (drystone storehouses) for the winter.Visitors thought the inhabitants and their clothes smelled unpleasantly of fish and seabirds.

- Fishing was important, but at times was impossible due to the unpredictable weather and heavy seas.

- The islanders destroyed large areas of potential farm land by stripping turf near the village for fires, rather than collecting peat from further away. ${ }^{6}$ The loss of the last pony by 1840 made peat collection from distant parts of the island more difficult. Many visitors, for example Wilson ${ }^{15}$ in 1842 and Heathcoate ${ }^{16}$ in 1900, drew attention to the problems this created.

- The arable land was a maximum of eighty acres and naturally poor, with thin stony topsoil and poor drainage. However, the islanders were able to improve the land temporarily with some careful husbandry and fertilisation.

- Much of the St Kildans' food produce, including most of their agricultural crops, ${ }^{6}$ was paid as rent and taken to Harris or consumed by visitors such as the steward's party or shipwrecked sailors, leaving a nutritionally limited diet of seabirds, eggs, fish and the less nutritious vegetables for the islanders. 
- Crops were mainly barley, oats and potatoes, but included lesser amounts of sea-plants, dulse (an edible seaweed), silverweed roots, dock, sorrel, scurvy-grass, rhubarb, turnips and cabbages. Peas and beans flowered without produce. Fruits were clearly a rarity.

- Vegetable production varied from year to year. Some years produced plentiful crops and 'the finest barley', but the growing season was short and there were other years of poor returns, inferior quality grain, poor management and adverse weather.

- Boiling was the usual method of cooking all meals, whether meat or vegetables. This would have further reduced the vitamin $C$ content. Dulse, however, was consumed raw. ${ }^{6}$

There is little evidence for the effect of low levels of vitamins on infection. The evidence for supplementation with vitamins $A$ or $C$ is controversial. Cochrane identified three trials assessing the role of vitamin $C$ in the prevention of pneumonia. ${ }^{17}$ These trials studied soldiers and English boys in a boarding school in the 1940s, and suggested that supplements of vitamin $C$ were beneficial in preventing pneumonia.

Cochrane also records another trial studying the role of vitamin $C$ in the treatment of pneumonia in the elderly (66-94 years old), and detected benefit only in patients with more severe illness and pre-existing low vitamin C levels. ${ }^{18}$ These studies are probably more relevant to the poor nutritional status of the St Kildans than to a general population.

Tetanus was another serious problem on St Kilda, and there is a possibility that vitamin $C$ deficiency may have contributed to the high death rate. The only relevant human study is a non-randomised open trial by Jahan ${ }^{19}$ in which patients with tetanus were allocated to the standard therapy of anti-tetanus serum, sedatives and antibiotics plus 1,000 mg ascorbic acid for some cases. In 3 I children aged one to 12 years, the death rate was zero in the ascorbic acid group, but $74.2 \%$ in the remaining group. In the older cohort aged I $3-30$ years, $37 \%$ of 27 in the vitamin C group died, compared with $67.8 \%$ of 38 patients in the remaining group, suggesting that higher levels of vitamin $\mathrm{C}$ may reduce the mortality of tetanus.

There is some evidence that zinc supplements reduce the frequency and severity of pneumonia in the elderly, and the severity of pneumonia and infective diarrhoea in children, particularly those with low levels of zinc. ${ }^{20,21}$ However, Meharg found very high soil levels of zinc on St Kilda, up to $500 \mathrm{mg} / \mathrm{kg}$, and there is therefore no evidence of clinical zinc deficiency. ${ }^{22}$

Meharg also found high levels of lead in the soil of arable areas of St Kilda.The lead and zinc levels are comparable with those found in the most polluted cities in UK. Heavy metals have many toxic effects, such as lead nephropathy, although they appear not to have a major direct effect on the immune system. Acute poisoning with cadmium fumes can cause pneumonitis, acute poisoning with thallium and zinc can cause diarrhoea and chronic exposure to nickel and chromium can cause pulmonary fibrosis.

In conclusion, there is no clear evidence of increased susceptibility to infection from the high levels of heavy metals found in the soil of St Kilda. Moreover, the limited information on food consumption on the island and current research elsewhere suggest that the people of St Kilda may have suffered more severely than expected from common infections because of their poor diet, particularly because of vitamin $C$ deficiency.

\section{DIOXIN}

Dioxin is a specific organic unsaturated non-antiaromatic six-membered ring compound with a chemical formula of $\mathrm{C}_{4} \mathrm{H}_{4} \mathrm{O}_{2}$. However, the term dioxin is used generically by most authorities to include chlorinated dioxins with furans and many derivative compounds as a complex of at least 75 ubiquitous and environmentally persistent organochlorine compounds, of variable toxicity. In 2008 dioxin contamination of Irish pork necessitated worldwide recall of this meat. Of the dioxins, 2,3,7,8-tetrachlorodibenzo-p-dioxin (TCDD) is the most studied and most toxic. It has been assigned a benchmark toxic equivalent factor (TEF) of I, such that all other dioxins have a TEF of less than I.

Dioxins are also believed to be carcinogenic. However, cancers were not a common problem on St Kilda, and this complex issue is beyond and irrelevant to the scope of this article. The major source of dioxin in any environment is inefficient waste incinerators burning organic carbon in the presence of chlorine. The major sources in the UK have been the organochlorine-based industries that developed rapidly in the 1950s, but Meharg has recently shown that the burning of coastal peat in Scotland produced dioxins well before the industrial revolution. ${ }^{22,23} \mathrm{He}$ performed his studies on St Kilda because of the detailed anthropological reports on the islands.

In Meharg's research, soil was taken both from the surface of the arable area and excavated from houses down to the time strata of 1800-1850. (A test for tetanus spores from the time strata of 1600-1900 would be of interest in view of the apparent absence of this disease in the seventeenth century. ${ }^{2}$ ) Meharg found that unburnt peat contained I I $4 \mathrm{ng} / \mathrm{kg}$ of dioxin and that burning peat produced $643 \mathrm{ng} / \mathrm{kg}$ of dioxin in the peat smoke and ash.

Tetrachlorodibenzofurans (TCDF) were the predominant dioxin found on St Kilda. Meharg estimated that each house on the island had four or five inhabitants and 
burnt $60 \mathrm{~m}^{3}$ of peat per year. This would give a total dioxin production by the estimated $260,000-420,000$ inhabitants of the Scottish highlands and islands in the eighteenth and nineteenth centuries of I kg/year, about one fifth of that produced by the whole of the UK in the industrial era. St Kildans stored the peat ash mixed with cow manure on the house floors over winter and used the mixture to fertilise the island's arable land in spring. There are still high levels of TCDF found in the arable area more than 70 years after the evacuation.

\section{Effects of dioxin on infections and the immune system}

\section{Animal studies}

The mammalian immune system has been shown to be susceptible to direct damage by low doses of dioxin, and indirectly by damage to the immuno-modulating effect of the hormonal system. Dioxins have been shown to alter the activity of glucocorticoids, sex steroids, thyroxine, growth hormone and prolactin.

Marmoset monkeys have been found to have abnormalities in white cells at dioxin levels of $10 \mathrm{ng} / \mathrm{kg}$, which is $25 \%$ below the average level found in American men and women. Dioxin directly reduced the number of both $B$ and $T$ lymphocytes, hence these monkeys may have an increased susceptibility to viral infections. Animal studies have also shown that dioxin toxicity can cause thymic involution, decreased antibody production with thymic dependent and independent antigens, and reduced cytotoxic T-cell function. Thurmond showed TCDD treatment causes a time-dependent response in the mature B-lymphocyte subpopulation, with a significant increase at day one, followed by a significant decrease by day nine and finally a return to baseline levels by day $31 .{ }^{24}$

Immune mechanisms usually provide protection against micro-organisms, but, with disruption causing upregulation of these pathways, normally beneficial elements can cause injury and exacerbate disease. Dioxin has been shown to affect cytokine production in virus infections. Interferon-gamma (IFN $\gamma$ ) is an important first line of defence against viral infections, but excess IFN $\gamma$ leads to increased inflammation with severe multi-organ damage and failure. Neff-LaFord and colleagues have shown in experimental mice that dioxin activates the aryl hydrocarbon receptor (AhR) during viral influenza infections, resulting in a downstream fourfold increase in IFN $\gamma$, with a peak level occurring after seven days compared with the usual five days, followed by increased pulmonary inflammation and an increased mortality. Mice exposed to dioxin may then die of a usually sublethal infection. ${ }^{25}$

Lawrence recently reviewed the effect of dioxins, and specifically TCDD, as modulators of the immune response. ${ }^{26}$ The list of effects, predominantly from animal studies, is summarised as follows:
- TCDD is a high affinity agonist for the AhR receptor, causing an enhanced innate response to many antigens. AhR activation causes increased pulmonary IFN $\gamma$ and excessive pulmonary recruitment of neutrophils, leading to excessive congestion and hypoxia.

- Increased incidence of respiratory infections.

- Mice exposed to TCDD have a higher mortality from herpes virus, coxsackie virus and influenza $A$ virus.

- The clonal expansion and differentiation of influenza virus-specific CD8+ $\mathrm{T}$ lymphocytes during primary infection is suppressed.

- Production of influenza virus-specific IgG antibodies is reduced, and delayed by about one week in reinfection.

- $\lg \mathrm{G}$ and IgM levels are reduced.

\section{Human studies}

Data are limited in humans, and research is ongoing. It is suggested that dioxin exposure increases the risk of avian $(\mathrm{H} 5 \mathrm{NI})$ influenza infection and that dioxin increases host susceptibility to infection by modulating the expression of Toll-like receptors. Dioxin can enhance viral replication, although the mechanism is obscure. Gollapudi studied cells exposed to dioxin, using the human immunodeficiency virus-I (HIV-I) as a model, and demonstrated a molecular and cellular basis for increased viral replication. ${ }^{27}$ Dioxin was found to increase production of tumour necrosis factor alpha (TNF $\alpha$ ) in promonocytic UI cells, increasing HIV-I gene expression and inducing cytokine production and thus leading to upregulation of HIV replication. The increased HIV production was inhibited by pentoxifylline, an inhibitor of TNF $\alpha$ synthesis. If the same mechanism applies equally to other viruses, dioxin could have increased the severity of infections such as rhinovirus and varicella among the St Kildans.

Dioxin accumulates in fatty food and therefore is augmented in the human food chain. Dioxins and the structurally and biologically similar polychlorinated biphenyls (PCBs) are also concentrated in breast milk, giving a breast-feeding infant 80 times the intake of both toxic chemical groups as the mother on a weight-forweight basis. ${ }^{28}$ Levels of PCBs are generally higher in the breast milk of European and North American women than in women from non-industrialised countries. Guan found higher levels of three dioxins in the milk of lactating mothers eating a lot of fatty meat and fish, ${ }^{29}$ precisely the diet of seabirds and fish on St Kilda. Barraza-Vazquez $z^{30}$ demonstrated a positive correlation between the maternal venous blood and umbilical cord levels of dichlorodiphenyltrichloroethane (DDT). Kreuzer tested preschool children in Michigan, finding mean serum PCB levels of $0.3 \mathrm{ng} / \mathrm{ml}$ in bottle-fed children, compared with $5.1 \mathrm{ng} / \mathrm{ml}$ in children who were breast-fed for more than six months. ${ }^{31}$

Therefore a pregnant St Kildan woman, living in her dioxin-contaminated village, would have exposed her 
fetus to minor amounts of dioxins in the mother's serum and transferred via the placenta, followed by much higher levels of dioxin in breast milk. The effect on the immune system of children in the first few days of life is uncertain, but one can speculate that this may have been a contributory factor to the neonatal tetanus problem.

\section{Clinical studies}

The clinical and practical significance of these epidemiological data and in-vitro studies, and of the dioxin on St Kilda, is uncertain. The island did not have regular medical surveillance. Haematological and biochemical testing was unavailable. Detailed medical observation and analysis of the clinical effects of dioxins on humans and their infections from low-level chronic toxicity elsewhere are unavailable. However, comparison with acute dioxin exposure and toxicity elsewhere permits an assessment of the severity of the problem on St Kilda.

The best-known episode of acute dioxin exposure is the Seveso accident near Milan in 1976, when an aerosol cloud of TCDD and other chemicals was released over an $18-\mathrm{km}^{2}$ area. ${ }^{32}$ The estimated amount of TCDD released was $34 \mathrm{~kg}$, compared with an estimated production of I kg/year in the Scottish highlands and islands in the nineteenth century. The area surrounding Seveso was classified into three zones, A, B and R, with decreasing levels of pollution. The levels of soil pollution and toxicity with dioxin compared with St Kilda are as follows:

- Seveso Zone A: $15,500-580,000$ ng/m²

- Seveso Zone B: $<5,000 \mathrm{ng} / \mathrm{m}^{2}$

- Seveso Zone R: I,500 ng/m²

- St Kilda peat: II4 ng/kg (I m³ dry soil = c. $700 \mathrm{~kg})$

The inhabitants of Seveso were extensively investigated and carefully followed. High blood levels of TCDD were found but no significant functional abnormalities in the immunological, hepatic, neurological and reproductive systems. In the longer term, an increase in carcinomas of the gastrointestinal tract and lymphatic systems and an increase in the death rate from respiratory disease were found. Exposed children in Zone A showed higher levels of complement activity, higher values for lymphocyte responses to phytohaemagglutinin and pokeweed mitogen and increased numbers of peripheral lymphocytes.

Chloracne affected a significant number of Seveso's inhabitants, too. This is an acne-like skin eruption, most marked behind the ears, on the cheeks and in the axilla and groin. It is a very obvious rash and considered the classical clinical feature of dioxin exposure. Viktor Yushchenko, the President of Ukraine, is considered to suffer from this condition, following an acute illness in 2004 in which his face became disfigured, scarred and pockmarked. Levels of dioxin in his blood were reported to be 6,000 times above the safe minimum, but the veracity of these tests are debated by toxicologists, and the possibility of deliberate poisoning is debated in political circles.

The St Kildan males grew heavy beards, but no pictures show chloracne in women or children, nor are there reports from visiting doctors or other sources nor photos of axillary or inguinal rashes in men. Chloracne rates in the age group 3-14 years inhabiting Seveso and St Kilda were:

- Zone A: 42 of 214 children

- Zone B: 8 of I,468 children

- Zone R: 63 of 8,680 children

- St Kilda: none documented and none visible on the many photographs of the island's children from $1880-1930$

Another smaller but relevant chemical leak occurred from a BASF trichlorophenol unit in Germany in 1953. ${ }^{33}$ The probable agent was also TCDD. Zober published a 36-year follow-up of the exposed workers, and compared the frequency of disease with that of BASF workers not present at the time of contamination using coded diagnoses of medical insurance claims. Again, the presence of chloracne was associated with higher levels of blood lipid TCDD concentrations. The calculated mean blood lipid levels were I, I I8 parts per trillion (ppt) in the severe chloracne group and 148 ppt in the no-chloracne group.

Thyroid disease and appendicitis were more common in the exposed group. Illness episodes were more common in the severe chloracne group than the reference group in each of the periods 1953-59, 1960-69 and 1970-89. Acute upper respiratory tract infections (URTIs) were significantly more common in the group with severe chloracne, at 15.8 per 100 person years, compared with 8.2 in the reference cohort. The rate was highest, at 18.8, in the severe chloracne group with TCDD levels of more than I,000 ppt. There was a non-significant increase in pneumonia and influenza in the severe chloracne group, as well as a non-significant increase in URTls in those with moderate or absent chloracne compared with the control group. As at Seveso, there was no significant health problem with those who did not have chloracne.

\section{CONCLUSION}

The St Kildans were clearly potentially exposed to high levels of dioxin and were more susceptible to infections than other Hebridean islanders. However, the dioxin levels on the island were an order of magnitude below those found in the lightly polluted areas around Seveso, where morbidity and mortality were not affected, and were even lower than in the highly polluted areas where clinical toxic effects were detected. Chloracne, the sine qua non of dioxin exposure, is not recorded on St Kilda. 
It seems only possible that dioxins on the island contributed to the inhabitants' morbidity, in the multifactorial context of a population with low herd immunity, malnutrition, an adverse climate and limited immunological biodiversity.

\section{REFERENCES}

I Mackenzie JB.Antiquities and old customs in St Kilda, compiled from notes made by Rev Neil Mackenzie, Minister of St Kilda 1829-43. Proc Soc Antiq Scot 1905; 39:397-402.Available from: http://ads.ahds.ac.uk/ catalogue/adsdata/PSAS_2002/pdf/vol_039/39_397_402.pdf

2 Stride P. St Kilda,the neonatal tetanus tragedy of the nineteenth century and some twenty-first century answers. J $R$ Coll Physicians Edinb 2008; 38:70-7.

3 Stride P. The St Kilda epidemic of I727, smallpox or chickenpox? J Royal Coll Physicians Edin 2009; 39:276-9.

4 Holohan AM. St Kilda: Emigrants and disease. Scot Med J 1986; 31:46-9.

5 Stride P. The St Kilda boat cough under the microscope. J Royal Coll Physicians Edinb 2008; 38:250-60.

6 Harman M. An isle called Hirte. Skye: Maclean Press; 1997.

7 Martin M. Description of the Western Islands of Scotland circa 1695 and a Voyage to St Kilda. Edinburgh: Birlinn; 1999. Available from: http://www.undiscoveredscotland.co.uk/usebooks/martinwesternislands/index.html

8 Buchan A. A description of Saint Kilda. Edinburgh: Lumisden and Robertson; 1732.

9 Macaulay K. The history of St. Kilda. London: Beckett and de Hondt; 1764.

10 Johnson S. A journey to the Western Isles of Scotland. Dublin: Leathley; I775. Available from: http://ebooks.adelaide.edu.au/j/ johnson/samuel/western

II MacDonald C. St Kilda: its inhabitants and the diseases peculiar to them. BM] I886; 2:I60-3. doi:I0.II36/bmj.2.1334.160-a

I2 Maclean C. St Kilda: island on the edge of the world. Edinburgh: Canongate; 1972.

I3 Robson M. St Kilda Church, visitors and 'natives'. Lewis: Islands Book Trust; 2005.

14 Steel T. The life and death of St Kilda. London: Fontana; 1975.

I5 Wilson J. A voyage round the coasts of Scotland and the isles. Vol II. Edinburgh: Adam and Charles Black; 1842.

16 Heathcoate N. St Kilda. London: Longmans, Green and Co; 1900.

17 Hemilä H, Louhiala P. Vitamin C for preventing and treating pneumonia (review). Cochrane Database Syst Rev 2007; (I):CD005532. Available from: http://mrw.interscience.wiley.com/ cochrane/clsysrev/articles/CD005532/pdf_abstract_fs.html

I8 Hunt C, Chakravorty NK, Annan G et al. The clinical effects of vitamin $C$ supplementation in elderly hospitalised patients with acute respiratory infections. Int J Vitamin Nutr Res 1994; 64:2 12 -9.

19 Jahan K, Ahmad K, Ali M. Effect of ascorbic acid in the treatment of tetanus. Bangladesh Med Res Counc Bull 1984; 10:24-8.

20 Meydani SN, Barnett JB, Dallal GE et al. Serum zinc and pneumonia in nursing home elderly. Am J Clin Nutr 2007; 86: I 167-73. Erratum in: Am J Clin Nutr 2008; 87: 1071.
Depopulation in 1930 may have prevented the exposure of the islanders to increasing levels of dioxin and heavy metal in future years, with significant detectable clinical toxicity.
2I Brooks WA, Yunus M, Santosham M et al. Zinc for severe pneumonia in very young children: double-blind placebo-controlled trial. Lancet 2004; 363:1683-8. doi: I0.1016/S0140-6736(04) I6252-I

22 Meharg AA. Polluting utopia: the idyllic reputation of a lost island community may not be wholly deserved. Nature 2005; 434:959. doi:I0.1038/434959a

23 Meharg AA, Killham K. Environment: a pre-industrial source of dioxins and furans. Nature 2003;421:909-10. doi:10.1038/421909a

24 Thurmond TS, Gasiewicz TA. A single dose of 2,3,7,8tetrachlorodibenzo-p-dioxin produces a time- and dose-dependent alteration in the murine bone marrow B-lymphocyte maturation profile. Toxicol Sci 2000; 58:88-95. doi:10.1093/toxsci/58.1.88

25 Neff-LaFord H, Teske S, Bushnell TP et al. Aryl hydrocarbon receptor activation during influenza virus infection unveils a novel pathway of IFN-gamma production by phagocytic cells. J Immunol 2007; 179:247-55.

26 Lawrence BP. Environmental toxins as modulators of antiviral immune responses. Viral Immunol 2007; 20:23I-42. doi:I0.1089/ $\operatorname{vim} .2007 .0013$

27 Gollapudi S, Kim CH, Patel A et al. Dioxin activates human immunodeficiency virus-I expression in chronically infected promonocytic UI cells by enhancing NF-kappa B activity and production of tumor necrosis factor-alpha. Biochem Biophys Res Commun 1996; 226:889-94. doi:10.1006/bbrc.1996.1445

28 Nickerson K. Environmental contaminants in breast milk. J Midwifery Womens Health 2006; 51:26-34. doi:10.1016/j. jmwh.2005.09.006

29 Guan P, Tajimi M, Uehara R et al. Associations between dietary intake and breast milk dioxin levels in Tokyo, Japan. Pediatr Int 2005; 47:560-6. doi:10.1III/j.1442-200x.2005.0212I.x

30 Barraza-Vázquez A, Borja-Aburto $\mathrm{V}$, Bassol-Mayagoitia $\mathrm{S}$ et al. Dichlorodiphenyldichloroethylene concentrations in umbilical cord of newborns and determinant maternal factors. J Appl Toxicol 2008; 28:27-34. doi:10.1002/jat. 1247

3I Kreuzer PE, Csanády GA, Baur C. 2,3,7,8-Tetrachlorodibenzo-pdioxin (TCDD) and congeners in infants. A toxicokinetic model of human lifetime body burden by TCDD with special emphasis on its uptake by nutrition. Arch Toxicol 1997; 71:383-400. doi:I0.1007/s002040050402

32 Bertazzi P, Bernucci I, Brambilla G et al. The Seveso studies on early and long-term effects of dioxin exposure: a review. Environ Health Perspect 1998; 106:625-33. doi:10.2307/3433813

33 Zober A, Ott M, Messerer P. Morbidity follow up study of BASF employees exposed to 2,3,7,8-tetrachlorodibenzo-p-dioxin (TCDD) after a 1953 chemical reactor incident. Occup Environ Med 1994; 51:479-86. doi:I0.I I36/oem.5I.7.479 